NBSIR 80-2064

\title{
Chemical Degradation of Castable Refractories in Coal Gasification Process Environments
}

Carl R. Piobbins

Floyd A. Mauer

Center for Materials Science

National Measurement Laboratory

National Bureau of Standards

U.S. Department of Commerce

Washington, D.C. 20234

May 1980

Prepared for

The United States Department of Energy

Under Contract EA-77-A-01-6010 



\section{CHEMICAL DEGRADATION OF CASTABLE REFRACTORIES IN COAL GASIFICATION PROCESS ENVIRONMENTS}

Carl R. Robbins

Floyd A. Mauer

Center for Materials Science National Measurement Laboratory

National Bureau of Standards

U.S. Department of Commerce

Washington, D.C. 20234

May 1980

Prepared for

The United States Department of Energy

Under Contract EA-77-A-01-6010

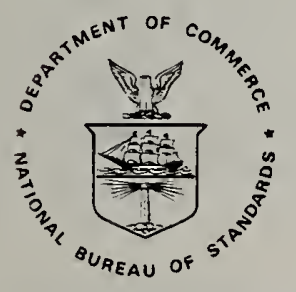

U.S. DEPARTMENT OF COMMERCE, Philip M. Klutznick, Secretary Luther H. Hodges, Jr., Deputy Secretary Jordan J. Baruch, Assistant Secretary for Productivity, Technology, and Innovation NATIONAL BUREAU OF STANDARDS, Ernest Ambler, Director 



\section{FOREWORD}

Since 1974, the National Bureau of Standards has been engaged in research designed to address materials problems and needs pertinent to coal conversion and utilization technologies. This work, sponsored in part, at first by the Office of Coal Research, then ERDA and currentiy the DOE, focuses on test method development, particularly accelerated procedures for materials behavior and durability; on the determination of the mechanisms of materials degradation; and on the development and operation of materials data centers to provide evaluated information on properties and performance including failures occurring in operating plants.

During the FY 77-79 period the NBS program, entitied "Materiais Research for the Clean Utilization of Coal" consisted of a number of interrelated tasks including:

1. Metal Corrosion

a. Constant Strain Rate Test

b. Pre-cracked Fracture Test

2. Ceramic Deformation, Fracture and Erosion

3. Chemical Degradation of Ceramics

a. Reactions and Transformations

b. Slag Characterization (viscosity)

c. Vaporization and Chemical Transport

4. Failure Prevention

a. Failure Information Center

b. Materials Properties Data Center

The results of the research have been disseminated through quarteriy reports of progress (available from NTIS; report designation EA-6010; Dist. Category UC-90C) as well as numerous scientific publications in technical journals. Further, as individual tasks are completed, an overall report is prepared detailing the results and accomplishments of the project. This present publication is the final report for Task 3 a. Reactions and Transformations.

SAMUEL J. SCHNEIDER

Program Manager

Center for Materials Science

National Bureau of Standards 



\section{TABLE OF CONTENTS}

I. OBJECTIVE AND SCOPE OF WORK .............. 2

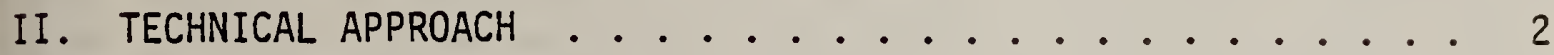

III. METHOD AND EQUIPMENT .................. 4

IV. RESULTS AND CONCLUSIONS .............. 7

A-94 Exposure Tests . . . . . . . . . . . . 9

A-56 Exposure Tests . . . . . . . . . . 10

Conoco Pilot Plant Samples . . . . . . . . . 12

Summary .................. . . 13

Figures .................. . . . 14

v. PUBLICATION AND TALKS ................... 25

VI. REFERENCES .................... 26 



\section{ABSTRACT}

Reactions and transformations that result in chemical degradation of castable refractories used as liners for coal gasification reactors have been studied. In addition to phase analys is of laboratory and pilot plant specimens by conventional $x$-ray powder diffraction, a new test method was developed that permits changes in the phase composition to be observed without removing the specimen from the test atmosphere. Two candidate castable refractories were included in the study, a high purity $\mathrm{CaO}-\mathrm{Al}_{2} \mathrm{O}_{3}$ composition with tabular alumina aggregate $(93.7 \mathrm{wt} \%$ $\mathrm{Al}_{2} \mathrm{O}_{3}, 5.6 \mathrm{wt} \% \mathrm{CaO}$ ) and a $\mathrm{CaO}-\mathrm{Al}_{2} \mathrm{O}_{3}-\mathrm{SiO}_{2}$ composition with calcined kaolinite aggregate $\left(55\right.$ wt $\% \mathrm{Al}_{2} \mathrm{O}_{3}, 36$ wt $\% \mathrm{SiO}_{2}, 5$ wt \% CaO). Specimens were exposed to steam, steam/ $\mathrm{CO}_{2}$, and a simulated coal gasification a tmosphere at a pressure of $7 \mathrm{MPa}$ (1000 psig) and temperatures up to $1000{ }^{\circ} \mathrm{C}$. Frequent changes in the bonding phases, and intervals in which a bonding phase was in transition were observed in the case of the high purity castable refractory. The silica-containing refractory, on the other hand, formed bonding phases which were stable in steam over a large range of temperatures and pressures. 


\section{CHEMICAL DEGRADATION OF CASTABLE REFRACTORIES \\ IN COAL GASIFICATION PROCESS ENVIRONMENTS}

\section{OBJECTIVE AND SCOPE OF WORK}

Coal gasification processes require the handling and containment of corrosive gases and abrasive particles at high temperatures and pressures. These severe environments cause materials failures which inhibit successful operation and increase costs. The objective of the program at the National Bureau of Standards is to provide test methods and data for evaluating properties of candidate materials under the conditions encountered in coal gasification process plants. The scope of this report is limited to castable refractories for use as liners of reactor vessels. It covers the reactions and transformations that result in chemical degradation when these materials are subjected to typical coal gasification process environments.

\section{TECHNICAL APPROACH}

Three different approaches have been used at NBS in studying reactions and transformations in candidate refractory castables for gasification reactor liners. The first, or post-exposure approach involved exposure of test bars in hydrothermal pressure vessels, followed by strength tests and $x$-ray analysis of phase composition after removal from the pressure vessel. A detailed discussion of the correlation of physical properties with phase assemblages observed after exposure is given in the report on Task 2 - Ceramic Deformation, Fracture and Erosionl. In addition, some of the earlier results have been summarized in a report by Wiederhorn et al ${ }^{2}$.

The second, or in situ approach was undertaken because the massive nature of the pressure vessels used for hydrothermal exposure limits the cooling rate so that conditions that prevail at high pressures and high temperatures cannot be effectively quenched. Thus additional reactions and transformations may occur while the specimen is being brought to $25{ }^{\circ} \mathrm{C}$ and one atmosphere for testing and examination. It was to eliminate any uncertainty caused by such changes that the decision was made to carry out both the flexural strength measurements and the $x$-ray analysis in situ: that is, without removing the specimen from the chamber. New and highly specialized equipment was designed and built at NBS for this purpose. This report describes the apparatus, method, and results of the in situ $x$-ray analysis. The measurements of flexural strength will be described in a separate report.

The third, or pilot plant exposure approach was based on our examination of approximately forty core samples from the refractory lining of the Conoco Lignite Gasification Pilot Plant in Rapid City, South Dakota. These refractories show the effects of 5.5 years of plant operation, 0.76 years of which were at pressure and temperature $(0.9 \mathrm{MPa}$ and $843^{\circ} \mathrm{C}$ ). The results of characterization of core samples from the Conoco pilot plant by light microscopy, SEM and $x-$ ray powder diffraction have been reported by Dobbyn et a $7^{3}$. and have been summarized in a note by Brower et $\mathrm{l}^{4}$. Some of the findings will be discussed here in an 
attempt to correlate short term in situ test data with the effects of much longer exposure under actual service conditions.

Two candidate castable refractories were included in the laboratory study, a high-purity $\mathrm{CaO}-\mathrm{Al}_{2} \mathrm{O}_{3}$ composition with tabular alumina aggregate (NBS A-94) and a $\mathrm{CaO}-\mathrm{Al}_{2} \mathrm{O}_{3}-\mathrm{SiO}_{2}$ composition with calcined kaolinite aggregate (NBS A-56). Samples of $C \mathrm{CS}_{2}, \mathrm{CA}_{2}, C A_{6}$ and $C \bar{C}^{*}$ were also prepared in order to examine the behavior of these important compounds in more detail. The refractories were cast into bars $75 \times 15 \times 7.5 \mathrm{~mm}$ and cured for 24 hours in an environment of 100 percent relative humidity. The bars were then dried at $110^{\circ} \mathrm{C}$ for 24 hours and stored in a desiccator for later use in in situ testing. Some were fired for five hours at $1010{ }^{\circ} \mathrm{C}$ before testing in order to compare the response of fired and unfired specimens to the test atmosphere. Specimens were exposed to steam, steam $/ \mathrm{CO}_{2}$ and to a simulated gasification atmosphere (Table 1 ) at pressures up to $7 \mathrm{MPa}^{\top}$ and temperatures up to $1000{ }^{\circ} \mathrm{C}$. The composition of

Table 1. Nominal composition of the simulated coal gasification atomsphere at approximately $850{ }^{\circ} \mathrm{C}$ and $7 \mathrm{MPa}$.

\begin{tabular}{lc}
\hline Component & Amount (Mole \%) \\
\hline $\mathrm{CO}$ & 20 \\
$\mathrm{CO}_{2}$ & 15 \\
$\mathrm{H}_{2}$ & 25 \\
$\mathrm{H}_{2} \mathrm{O}$ (steam) & 40 \\
\hline
\end{tabular}

the atmosphere is difficult to predict if pressure as well as temperature is allowed to vary. It has been our policy to establish the nominal composition shown in Table 1 for a pressure of $7 \mathrm{MPa}$ and to maintain this pressure throughout each series of experiments. Results reported may be assumed to have been obtained at $7 \mathrm{MPa}$ unless otherwise noted. The change in composition with temperature has been examined thermodynamical1y at NBS by Dr. W. S. Horton. The steam and CO content each increase by roughiy $6 \%$ while the $\mathrm{CO}_{2}$ and $\mathrm{H}_{2}$ content decrease by a similar amount in the temperature range from $600^{\circ}$ to $1000^{\circ} \mathrm{C}$. The composition shown in the table is, therefore, representative of the middle of the range of experimental conditions covered and deviations from this composition do not exceed $\pm 5 \%$.

${ }^{*} \mathrm{C}=\mathrm{CaO}, \mathrm{A}=\mathrm{Al}_{2} \mathrm{O}_{3}, \mathrm{~S}=\mathrm{SiO}_{2}, \mathrm{H}=\mathrm{H}_{2} \mathrm{O}, \overline{\mathrm{C}}=\mathrm{CO}_{2}$

'The International Standard (SI) unit of pressure is the pascai, or newton per square meter. One mega pascal $(\mathrm{MPa})=10^{6}$ pascals. The conversion to $p s i g$ is given by $p(p s i g)=(p(M P a) \times 145)-14.7$. 


\section{NETHOD AVID EQUIPMENT}

llew and highiy speciaiized Equiptent was needed in order to obtain x-ray diffraction data witncut renoving the specinen from the pressure vessei. The equipment desicned and built at the lational sureau of standards for this purpose is based on the energy dispersive $x$-ray diffraction (EOXO) technicue described by Giessen and Gordon in is68.

Unlike conventional diffraction wethods, which use wonochromatic radiation and a range of diffraction angles, the EDXD method employs white (continuum) radiation and a fixed diffraction angle, $2 \lesssim$. The diffracted bea- is analyzed with a solid state detector and anltichannel pulse height snalyzer to determine the energy distribution of the photons. Sragg's iaw in the form given by Sparks and Gedckej

$$
E_{h k_{i}}=\frac{12.3981}{2 \sin s} \cdot \frac{1}{d_{h k i}}
$$

is used to calcuiate the energy E (in kilcelectron volts) of $x-r a y$ photons diffracted by planes of spacing $c_{h k i}$ (in angstrom units). The channei number, $i$, is given by

$$
N=(E-b) / z
$$

where a and b ars cailoration constants of the solid state detector systel. For the work reported here $==12.00^{\circ}$, a $=0.0353 \mathrm{keV} / \mathrm{channel}$, and $b=0.80 \mathrm{keV}$.

The outstanding advantage of the EDXD wethod for the present apoification is that it requires oniy a singie, narrow $x$-ray path through the pressure vessei. The entrance and exit windows can be as small as a cuarter of an inch in diameter, and it is relatively easy to obtain suitabie window material in the size and shape required. Using boron carbide, $3_{-}$, it was possibia to design for a pressure of 7 MPa with a suitable satety iactor wille keeping the windows thin enough for adequate transuission of the x-ray bean.

There are sacrifices that must be made as a trade-ofi for the sueed and convenience of the EDXD wethod. The wost serious is the low resointion of the detector, which resuits in peaks that are more than an order of magnitude wider than in conventional difiractonetry.

Details of the construction of the pressure vessel are shown in Figure $i$. The ucper view is a section through the vessel in the plane of diffraction. Radiation fron the $x$-ray source (A) passes through a $1 / 8$ irch thick window of boron carbide $(3)$ and, after being scattered by the suecieen (C), passes trrough a second window $(3)$ and siti $(0)$ to enter the soi id state detector (E). The bracket (F) which supports the scecimen has siots willed in it for the $x$-ray besn. These limit the divergence of the incident and diforacted beans to $2=$. An internal heater consisting of an aiumina core (G) wound with approximateiy 5 feet: of 0.032 inch diz-ezer $80 \%$ ? $-20 \%$ ih wire (H) surrounds the specimen 
bar. A concentric alumina tube ( $I$ ) is wrapoed with platinum foil (J) to reduce heat transfer by radiation. The heater assembly is mounted in a $U$-shaped bracket of 0.031 inch thick Inconel sheet $(M)$ which forms three sides of a box. The remaining three sides are formed by a cover ( $L$ ) of 0.010 inch thick Inconel. The space between the heater and the box is packed with fibrous alumina insulation. Internal windows of 0.002 inch thick mica mounted in platinum disks (V) ioosely cover the ends of the heater core to reduce convection currents while allowing the $x$-ray beam to pass. The importance of these disks should not be uncerestimated, as operating temperatures without them are limited to about $500^{\circ} \mathrm{C}$. Three thermocouples are provided. The first $(0)$ is attached to the front edge of the specimen at the top. The second $(P)$ is at the bottom of the vessel where it senses the temperature of the water that collects there. The third (not shown) is on the outside of the vessel in contact with the belt heater (not shown) that surrounds the vessel. Coned pressure fittings in ports $(Q)$ and $(R)$ are used to connect the gauge assembly and the water reservoir.

The pressure vessel, which is machined from $316 \mathrm{~L}$ stainless steel, is $41 / 2$ inch in $0 . d$. at the height of the $x-$ ray beam and has $1 / 2$ inch thick walls. The flange is 6 inches in diameter. Twelve 3/8-16 hightensile-strength bolts are used to attach the lid, which is fitted with a gold-plated $K$-shaped flange seal made of inconel $X-750$. The enclosed volume is approximately $435 \mathrm{ml}$. The side arms, which contain the $x$-ray windows, are also made of $316 \mathrm{~L}$ stainless steel and are welded in place at an angle corresponding to $2 €=24^{\circ}$. The boron carbide windows are sealed with gold plated $V$-gaskets of Inconel $x-750$. As the windows appeared somewhat grainy even after they were polished, the surfaces in contact with the gaskets were sputtered with gold to fill any irregularities and provide a softer seat. Threaded caps compress the gaskets and support the load due to gas pressure.

In operation, the pressure vessel is mounted as snown in Figure 2. A base assembiy supports both the pressure vessel and the solid state detector and provides the necessary adjustments for alignment. This base is pivoted at a point directly below the focal spot of the $x$-ray tube for ease in setting the take-off angle. Three leveling screws are used for setting the height and for making small adjustments to the angle of incidence. The base supports a heavy ring $81 / 4$ inches in diameter in which the oressure vessel is clamped by four $3 / 8$ inch radial set screws, the ends of which extend into holes in the six inch flange of the vessel. In addition to supporting the pressure vessel the mounting ring provides a means for counteracting the force applied in tightening the 1 id bolts. There are $123 / 8$ inch holes drilled vertically through the ring. A 10 inch lever is attached by means of pins that fit any diametrical pair of holes. Equal and opposite forces applied to this lever and the wrench provide the necessary torcue to tighten the bolts without disturbing the alignment of the instrument.

Since the vessel must often be operated with its walis at temperatures as high as $285^{\circ} \mathrm{C}$ in order to maintain a steam pressure of $7 \mathrm{MPa}$, it is equipped with an external belt heater visible just beiow the $x$-ray 
ports in Figure 2. While heating the vessel, it is important to minimize the heat transferred to the base, the detector, and the $x-r a y$ tube. with this aim, the $i . d$. of the mounting ring was made $1 / 4$ inch greater than the o.d. of the vessal flange. The four set screws comprise the only path for the conduction of heat from the vessel to the mount. A heavy copper sheet with a $1 / 8$ inch aperture is mounted between the exit slit and the detactor window to aid in the dissipation of heat that might otherwise be transierred to the detector. The only direct link between the vessel and the $x$-ray tube is a stainless steel beam tunnel that iits inside the safety shutter. Although this tunnel has thick walls (to reduce $x$-ray leakage) heat transier to the $x$-ray tube has not been a problem.

External fittings visible in Figure 2 include the gauge block assembly and the water reservoir. The gauge block provides, in addition to the gauge, a pressure tubing connection for introducing gases, a needle valve, and a rupture disk. The water reservoir has a capacity of $40 \mathrm{ml}$. It is pressurized with nitrogen gas to ensure that water will flow into the pressure vessel when the needle valve is opened.

The lid of the pressure vessel is fitted with two pressure seal assemblies for electrical leads, one for the four themocouple leads, and the other for a single power lead rated at 40 amperes. The vessel itseli serves as the conductor for the grounded side of the low voltage power supply of the internal heater.

A safety snield of $1 / 4$ inch thick steel is installed before the vessel is pressurized. A portion of this shield can be seen behind the pressure vessei in Figure 2. The enclosure is connected to an exhaust system in case of leakage of test atmospheres containing $\mathrm{CO}, \mathrm{H}_{2}$, or $\mathrm{H}_{2} \mathrm{~S}$.

After installing the specimen bar with the thermocouple attached, an initial charge of $20 \mathrm{ml}$ of water is added to the vessel before closing the lid. A.pproximately $15 \mathrm{ml}$ would be required to pressurize the vessel with saturated steam at $7 \mathrm{MPa}$. Excess liquid remains at the bottom of the vessel and its temperature is controlled by means of the externai heater to waintain the desired partial pressure of steam. Other components of the atmosphere are added as gases to obtain the desired total pressure. A resarve supply of water is kept in the $40 \mathrm{ml}$ reservoir to replenish any used in hydrating the sample or lost during the run.

The wall temcerature required to maintain a steam pressure of $7 \mathrm{MPa}$ is aporoximateiy 285 =C. The external belt heater has a rating of 650 watts at $240 \mathrm{~V} \mathrm{ac}$, but the power input during steady-state operation does not exceed 400 watts.

Specimen temperature is separately controlled using the internal heater. The maximum current recuired for control at $1000^{\circ} \mathrm{C}$ in staam is 14 amperses, corresponding to a power input of 390 watts. As the power input to the internai heater is increased, that to the externai heater 
must be reduced to compensate. A small blower has been installed in case additional cooling is required. It is not generally needed.

Specimen temperature is usually increased in increments of $50{ }^{\circ} \mathrm{C}$. Diffraction patterns are recorded after 6 hours, and again after 24 hours. A series of experiments covering the range to $1000^{\circ} \mathrm{C}$ and $7 \mathrm{MPa}$ requires from 3 to 6 weeks.

Reference patterns of known phases occurring in refractory cements are needed in order to recognize these phases when they are encountered in the course of an experiment. Since energy dispersive $x$-ray diffraction patterns differ considerably from those prepared with a conventional diffractometer, a special set of reference standards had to be prepared. Actually two sets of standards were prepared, one by obtaining samples of the desired material and recording the pattern with the EDXD apparatus, and the other by calculating the pattern from data given in standard references such as the Powder Diffraction File $e^{7}$. An example of an actual EDXD pattern for a-quartz is given in Figure 3 . Calculated patterns are given for $\mathrm{AH}, \mathrm{AH}_{3}, \mathrm{C}_{3} \mathrm{AH}_{5}, \mathrm{C}_{4} \mathrm{~A}_{3} \mathrm{H}_{3}$, and $\mathrm{C} \overline{\mathrm{C}}$ (Figure 4), for $\alpha-A, C A_{5}, C A_{2}, C A, C_{3} A$ and $\beta-A$ (Figure 5), and for $\alpha-S_{q}$ (quartz), $S_{C}$ (cristobalite), $\mathrm{A}_{3} \mathrm{~S}_{2}$ (mulitite) and low $\mathrm{CAS}_{2}$ (Figure $\sigma$ ). In addition to being compact and convenient to reproduce, the computed patterns have the advantage that a tabulation identifying all of the lines is available. When a peak is composed of a number of unresolved lines, the components are clearly shown in the computed pattern.

Computer methods used to assist in the interpretation of the sixty or more EDXD patterns resulting from each test included (1) automatic plotting of the patterns on a common axis system for ease in comparison, (2) subtraction of corresponding ordinates and plotting of the difference to show subtle changes, and (3) plotting of the intensity of selected lines for a series of patterns recorded over a range of pressure and temperatures. Examples will be included in section IV - RESULTS AND CONCLUSIONS.

\section{RESULTS AND CONCLUSIONS}

The approximate bulk compositions of the castable refractories NBS A-94 and NBS A-56 are shown by squares on the phase diagram of the system $\mathrm{CaO}-\mathrm{Al}_{2} \mathrm{O}_{3}-\mathrm{SiO}_{2}{ }^{3}$ (Figure 7 ). The chemical analyses are given in Table 2. 
Table 2. Chemical analyses (dried basis) of castable refractories (weight percent)

NBS $A-94$

93.7

5.6

0.1

0.3

0.3
NBS $A-56$

55.

5.

36 .

1.3

2.7

Others and
on ignition

In general, the in situ experiments were designed to monitor the behavior of an unfired castable during its initial heating, during exposure at $1000{ }^{\circ} \mathrm{C}$ and $7 \mathrm{MPa}$ and during the c00ling down phase of the cycle. Specimens were examined before and after exposure tests by conventional $x$-ray powder diffractometry. A list of the compounds observed is given in Table 3. Some are metastable, others such as the calcium aluminates may conta in $\mathrm{H}_{2} \mathrm{O}$ (al though shown here as anhydrous), and several of the hydrated calcium aluminates may be non-stoichiometric with respect to $\mathrm{H}_{2} \mathrm{O}$.

Table 3. Compounds encountered in exposure studies of A-94 and A-56

$C_{3} A$

$\mathrm{C}_{12} \mathrm{~A}_{7}$

$C A$

$\mathrm{CA}_{2}$

$\mathrm{CA}_{5}$

$C_{4} A_{3}$
$\mathrm{C}_{2} \mathrm{AH}_{3}$

$\mathrm{CAH}_{10}$

$\mathrm{C}_{3} \mathrm{AH}_{5}$

$\mathrm{C}_{4} \mathrm{~A}_{3} \mathrm{H}_{3}$

$C \bar{C}$

$\mathrm{CH}$
$3-C_{2} S$

$\mathrm{C}_{8} \mathrm{~S}_{5}$

$C_{2} A S$

$\mathrm{CAS}_{2}$ (2 forms)

$s_{c}, s_{q}$
$\alpha-A$

$3-A_{\text {SS }}$

$\mathrm{AH}$

$\mathrm{AH}_{3}$

$\mathrm{A}_{3} \mathrm{~S}_{2}$

$C=\mathrm{CaO}, A=\mathrm{Al}_{2} \mathrm{O}_{3}, \mathrm{~S}=\mathrm{SiO}_{2}\left(\mathrm{~S}_{\mathrm{q}}\right.$ quartz or $\mathrm{S}_{\mathrm{C}}$ cristobalite) $\mathrm{H}=\mathrm{H}_{2} \mathrm{O}, \bar{C}=\mathrm{CO}_{2}$

Steam is usually the chemically dominant component of the test atmosphere, as shown by the response of refractories to simulated or actual gasification environments. In the experiments described below the total pressure was maintained at $7 \mathrm{MPa}$, the design 7 imit for our apparatus, except for a few cases when the test temperature was so low that the equilibrium vapor pressure of water was too low to sustain the 
desired pressure. This condition occurred below $285^{\circ} \mathrm{C}$ for the steam atmosphere or $230{ }^{\circ} \mathrm{C}$ for the simulated gasification environment. The estimated total pressure is given only when it is lower than $7 \mathrm{MPa}$.

\section{A-94 Exposure Tests}

The composition of A-94 is represented by a square on the join CaO$\mathrm{Al}_{2} \mathrm{O}_{3}$ of the $\mathrm{CaO}-\mathrm{Al}_{2} \mathrm{O}_{3}-\mathrm{SiO}_{2}$ phase diagram (Figure 7 ). The compound assemblage commonly observed in cast and dried (but unfired) test bars includes: $C A, C A_{2}, \alpha-A, C A H_{10}, C_{2} A H_{8}, C_{3} A H_{5}$, and $A H_{3}$. The aggregate is tabular alumina.

With increasing temperature, the A-94 refractory passes through a sequence of phase assemblages consisting of hydrated calcium aluminates, hydrated aluminates, and $\alpha-A$. The sequence observed in steam, with approximate equilibrium dissociation temperatures, is

$\mathrm{CAH}_{10}+\mathrm{AH}_{3} \stackrel{20^{\circ} \mathrm{C}}{\longrightarrow} \mathrm{C}_{3} \mathrm{AH}_{6}+\mathrm{AH}_{3} \stackrel{170^{\circ} \mathrm{C}}{\longrightarrow} \mathrm{C}_{3} \mathrm{AH}_{6}+\mathrm{AH} \stackrel{240^{\circ} \mathrm{C}}{\longrightarrow} \mathrm{C}_{4} \mathrm{~A}_{3} \mathrm{H}_{3}+\mathrm{AH} \stackrel{345^{\circ} \mathrm{C}}{\longrightarrow} \mathrm{C}_{4} \mathrm{~A}_{3} \mathrm{H}_{3}+\mathrm{A} \stackrel{625^{\circ} \mathrm{C}}{\longrightarrow} \mathrm{CH}_{2}+\mathrm{A}$

in general agreement with the pseudobinary diagram of Crowley for the system $\mathrm{CaO}-\mathrm{Al}_{2} \mathrm{O}_{3}-\mathrm{H}_{2} \mathrm{O}$ at $100 \mathrm{MPa}{ }^{9}$. Above about $625{ }^{\circ} \mathrm{C}$ none of the hydrated phases is stable. At this point $\mathrm{CA}_{2}$ forms as the bonding phase, and the assemblage $C A_{2}, \alpha-A$ (with a trace of $\beta-A$ ) is observed in all tests up to $1000^{\circ} \mathrm{C}$. The reactions are reversible and have been followed by the in situ method. The bonding phases $\mathrm{C}_{3} \mathrm{AH}_{6}$ and $\mathrm{AH}_{3}$ dissociate over a rather narrow temperature interval compared with $\mathrm{C}_{4} \mathrm{~A}_{3} \mathrm{H}_{3}$ and $\mathrm{AH}$. $\mathrm{C}_{3} \mathrm{AH}_{6}$ forms readily in saturated water vapor at $\sim 93{ }^{\circ} \mathrm{C}$ and dissociates at $\sim 240{ }^{\circ} \mathrm{C}$ and $3.3 \mathrm{MPa} . \mathrm{C}_{4} \mathrm{~A}_{3} \mathrm{H}_{3}$, which forms above $\sim 240{ }^{\circ} \mathrm{C}$ and 3.3 $\mathrm{MPa}$, persists to $\sim 625^{\circ} \mathrm{C}$. It is the most difficult phase in the system to monitor by the EDXD method because of the weak and poorly resolved $x-$ ray pattern.

AH (boehmite) has been shown in NBS work under Task 2, Ceramic Deformation, Fracture and Erosion, to be one of the most important phases in the high purity castable refractory A-94. The observed loss of flexural strength of this refractory has been correlated with the decomposition of this compound. The "equilibrium" dissociation temperature of $\mathrm{AH}$ is $345^{\circ} \mathrm{C}$. However, with rising temperature, this dissociation was repeatedly observed to occur over a range of $\sim 200^{\circ} \mathrm{C}$. Small amounts of $\mathrm{AH}$ are cormonly present at $\sim 500^{\circ} \mathrm{C}$. The compound decomposes rapidly above $500^{\circ} \mathrm{C}$, and a refractory containing appreciable amounts of the hydrate should not be heated rapidly through this temperature region.

The ability of the in situ method to follow the dissociation of $A H$ in real time is shown by the series of four $x$-ray patterns reproduced in Figure 8. The overall change is shown in a difference plot, Figure 9 , in which the negative peaks correspond to the AH phase consumed in the reaction, while the positive peaks show the increase in $a-A$, the reaction product. 
Physical properties, such as strength and erosion resistance, which are affected by the presence of $A H$, can be expected to follow trends somewhat parallel to the formation or dissociation of this phase. For example, the flexural strength of the test bar used in this series of experiments might be expected to show the same trend as the intensity of the $x$-ray pattern of the AH phase.

In Figure 10 the intensity of the 251 reflection of $\mathrm{AH}$ (channel $610)$ and the intensity of the 116 reflection of $\alpha-A$ (channel 492 ) have been plotted for a sequence of fourteen experiments covering the range from $247{ }^{\circ} \mathrm{C}$ and $3.2 \mathrm{MPa}$ to $650{ }^{\circ} \mathrm{C}$ and $4.1 \mathrm{MPa}$ in steam. There was a substantial loss of AH during 21 hours at $375{ }^{\circ} \mathrm{C}$ and $3.8 \mathrm{MPa}$ (experiment 8) and at each subsequent temperature - pressure increment up to $650^{\circ} \mathrm{C}$ and $4.1 \mathrm{MPa}$ (experiment 14). Under the conditions of these experiments the flexural strength of the test bar would be expected to decrease at temperatures from $375{ }^{\circ} \mathrm{C}$ to $650{ }^{\circ} \mathrm{C}$ at $\sim 4 \mathrm{MPa}$ in steam.

In steam $/ \mathrm{CO}_{2}$, or in the simulated gasification environment, formation of hydrated calcium aluminates may be suppressed by the reaction of $\mathrm{CaO}$ with $\mathrm{CO}_{2}$ to form $\mathrm{CaCO}_{3}$. This compound dissociates in the presence of steam at $\sim 700{ }^{\circ} \mathrm{C}$, which is generally above the stability range of the hydrated phase.

Addition of dissolved silica to a test atmosphere of high pressure steam results in formation of a reaction rim $\sim 1 \mathrm{~mm}$ thick formed on test bars of high purity A-94. The reaction rim was composed mainly of $C_{2} A S, \beta-C S, C A_{2}$, and $\alpha-A$. Formation of hydrated calcium aluminates was thus inhibited. Since silica impurities in coal would be expected to contribute dissolved silica to the pressurized steam of a gasification reactor, similar reactions between dissolved silica and an initially high purity calcium aluminate castable can be expected to occur.

\section{A-56 Exposure Tests}

As may be seen from Figure 7 , the composition of A-56 lies in the compatibility triangle $\mathrm{A}_{3} \mathrm{~S}_{2}$ (mullite) - $\mathrm{CAS}_{2}$ (anorthite) - S (quartz, tridymite or cristobalite). The phase assemblage of the as-cast test bars is quite complex. Hydrated compounds such as $\mathrm{AH}, \mathrm{AH}_{3}, \mathrm{CAH}_{10}$, $\mathrm{C}_{2} \mathrm{AH}_{8}$ and $\mathrm{C}_{3} \mathrm{AH}_{6}$ are cormonly present as minor phases in addition to the anydrous major phases $S_{C}, A_{3} S_{2}, C A$ and $C A_{2}$. As the temperature is raised, in the presence of steam or the gasification atmosphere, hydrated phases gradually dissociate. The dominant reaction is in the ma in, a hydrothermal one, with high pressure steam interacting with $C A, C A_{2}, \alpha-A$ and $S_{c}$ to form the very strong bonding phase $\mathrm{CAS}_{2}$ (anorthite) and the stable assemblage $\mathrm{CAS}_{2}, \mathrm{~A}_{3} \mathrm{~S}_{2}, \mathrm{~S}$. This assemblage is subject to leaching in an open system such as a gasification reactor. Loss of $\mathrm{SiO}_{2}$ to the high pressure steam is commonly observed in the in situ experiments. The dissolved silica is usually precipitated as cristobalite, or a mixture of cristobalite and quartz depending on temperature and time of cooling. 
Only the triclinic form of $\mathrm{CAS}_{2}$ was observed in the in situ studies, but a hexagonal (metastable) form was observed in some of the postexposure studies of the Ceramic Deformation and Erosion specimens (Task 2) and in some of the Conoco refractories. This phase may form hydrothermally, by crystallization from high-temperature melts in air, and by solid state reactions. It rapidly transforms to triclinic $\mathrm{CAS}_{2}$ in the presence of steam below $700{ }^{\circ} \mathrm{C} 10$.

For NBS A-56 and several commercial $\mathrm{CaO}-\mathrm{Al}_{2} \mathrm{O}_{3}-\mathrm{SiO}_{2}$ castables studied, there is a passage from complex to much simpler phase assemblages with rising temperature in high pressure environments containing steam. By a variety of paths and reactions, the composition produces the stable assemblage $A_{3} S_{2}, S, C A S_{2}$ previously referred to in Figure 7 . The formation of new compounds at the expense of others is primarily a function of temperature at $7 \mathrm{MPa}$. Alumina gels, $\alpha-A, C A, C A_{2}$, and the various hydrated calcium aluminates react with $S_{c}$ to form the bonding phase $\mathrm{CAS}_{2} \cdot \mathrm{CAS}_{2}$ was observed forming in the 350-550 ${ }^{\circ}$ temperature range and more rapidly at $700^{\circ}-1000^{\circ} \mathrm{C}$.

Compared with the unfired test bars, those fired in air at $1010{ }^{\circ} \mathrm{C}$ for 20 hours show a large increase in $\mathrm{CA}_{2}$, a slight increase in $\mathrm{A}_{3} \mathrm{~S}_{2}$, the presence of poorly crystallized $C_{2} A S^{2}$ and $C_{A S}$, a decrease in $\alpha-A$ and $S_{C}$, and the absence of hydrated forms. As before, with exposure to the hydrothermal environment at $7 \mathrm{MPa}$ this assemblage is changed to $\mathrm{CAS}_{2}, \mathrm{~A}_{3} \mathrm{~S}_{2}$ and $\mathrm{S}$ with silica in the cristobalite form. The fiexural strength of the castable is markedly increased as these reactions progress in the gasification atmosphere.

Two supplementary experiments with test bars near $\mathrm{CAS}_{2}$ in composition were conducted in a steam atmosphere. The unfired bars consisted initially of $\mathrm{CA}, \mathrm{CA}_{2}$ and silica, with an excess of $A$. After casting, the bars were composed of $\mathrm{SiO}_{2}$ (quartz form), $\alpha-A, C A$, and $\mathrm{AH}_{3}$. X-ray analys is gave no indication of a gel phase. Exposure times were 168 and 330 hours. In both series of experiments, some hydration and subsequent dehydration of free alumina as well as the dissolution of free silica was observed as temperatures and steam pressures were increased. Formation of hydrated calcium aluminates was not observed. At approximately $160{ }^{\circ} \mathrm{C}$ and $0.5 \mathrm{MPa} \mathrm{Ca}_{8} \mathrm{Si}_{5} \mathrm{O}_{18}$, a phase not previously encountered in these studies, was formed in preference to hexagonal or triclinic $\mathrm{CAS}_{2}$. According to Speakman et al. $11 \mathrm{Ca}_{8} \mathrm{Si}_{5} \mathrm{O}_{18}$ is metastable, and of variable composition. The compound, along with free silica, persisted to $525{ }^{\circ} \mathrm{C}$. In the temperature interval $525-625{ }^{\circ} \mathrm{C}, \mathrm{Ca}_{8} \mathrm{Si}_{5} \mathrm{O}_{18}$ dissociated and/or reacted with the $\mathrm{SiO}_{2}$ to form triclinic $\mathrm{CAS}_{2}$. This is shown in the in situ $x$-ray pattern of Figure 11 (a), (b), and (c). Pattern (a) is of the unfired test bar at $25{ }^{\circ} \mathrm{C}$ and ambient pressures. Pattern (b) was recorded at $520{ }^{\circ} \mathrm{C}$ and $7 \mathrm{MPa}$ steam and shows the presence of well developed $\mathrm{Ca}_{8} \mathrm{~S}_{5}$ as indicated by two prominent diagnostic peaks. Pattern (c) was obtained one hour later after the temperature had been raised to $625{ }^{\circ} \mathrm{C}$ and $7 \mathrm{MPa}$ steam. It shows that at this temperature, most of the $\mathrm{Ca}_{8} \mathrm{~S}_{5}$ had dissociated/decomposed, releasing $\mathrm{CaO}$ for the formation of $\mathrm{CAS}_{2}$. The presence of $\mathrm{Ca}_{8} \mathrm{Si}_{5} \mathrm{O}_{18}$ suppresses the formation of $\mathrm{CAS}_{2}$ by incorporating available $\mathrm{Ca}$. Its occurrence in a refractory would appear to be undesirable. 


\section{Conoco Pilot Plant Samples}

In addition to the in situ tests of A-56, results of exposure of two similar commercial refractories to service conditions in the Conoco Lignite Gasification Pilot Plant are available. Approximately 40 core samples were examined by optical microscopy, SEM, and x-ray powder diffractometry. The following generalizations are based on the examination of the Conoco samples as well as on the in situ tests.

1) The atmosphere of a coal gasification reactor is a complex mixture of gases. Steam is the dominant component of this mixture as shown by chemical and structural changes in the $\mathrm{CaO}-\mathrm{Al}_{2} \mathrm{O}_{3}=\mathrm{SiO}_{2}$ refractory.

2) A hydrothermal reaction in which $\mathrm{SiO}_{2}$ in the form of cristobalite $\left(S_{C}\right)$ progressively reacts with free $\alpha-A, A_{3} S_{2}$ and the calcium aluminate binder $\left(\mathrm{CA}, \mathrm{CA}_{2}\right)$ to form the bonding phase $\mathrm{CAS}_{2}$ (anorthite) is seen to be the dominant reaction in laboratory and pilot plant studies.

3) Pilot plant specimens show a loss of $\mathrm{SiO}_{2}$ from the calcined kaol in aggregate (reaction rims). Some of the silica reacts to form $\mathrm{CAS}_{2}$ : At $\sim 900{ }^{\circ} \mathrm{C}$ some silica reacts with free $\alpha-A$ to form $A_{3} S_{2}$, and some is lost from the refractory, precipitating in regions of lower temperature as cristobalite or a mixture of cristobalite and quartz. The latter was frequently observed in the in situ tests.

4) Evidence of the apparent fluxing action of alkalies, resulting in surface melting at the working face of the refractories and the formation of a residual crust $\sim 2-3 \mathrm{~mm}$ in thickness was observed. Alkali reaction with the refractories was also shown by the presence of $\left(\mathrm{Na}_{1}{ }_{5} \mathrm{~K}_{0}{ }_{.5}\right) \mathrm{Al}_{2} \mathrm{Si}_{2} \mathrm{O}_{8}$ (Nephel ine, idealized formula) near the hot or working face of refractory specimens from the pilot plant.

5) The formation of hexagonal $\mathrm{CAS}_{2}$ was not observed in the in situ X-ray studies, but was obtained hydrothermally in work of the NBS Fracture and Deformation Task group in selected high pressure experiments. The compound may be formed by cooling from the melt, by solid state reactions, or hydrothermally. It is considered to be a metastable form and transforms rapidly below $700^{\circ} \mathrm{C}$ in the presence of steam to the triclinic form. It should be noted that the $700^{\circ} \mathrm{C}$ region would represent a temperature interval in which the primary bonding phase of the refractory is in a state of transition. The hexagonal form of $\mathrm{CAS}_{2}$ was observed as a minor phase in a number of specimens of pilot plant refractories taken 3 to 6 inches from the working face of the castable. 
6) As previously described, when reactions in test bars approximating the composition $\mathrm{CAS}_{2}$ (composed of $C A_{1}, \mathrm{CA}_{2}$, and $\mathrm{S}$ in the form of powdered quartz) were monitored by the in situ $x-$ ray method, the metastable compound $\mathrm{C}_{8} \mathrm{~S}_{5}$ was observed to form quite rapidiy at $160^{\circ} \mathrm{C}$ and $0.5 \mathrm{MPa}$. Formation of this compound suppressed the formation of $\mathrm{CAS}_{2}$ by incorporating the available calcia. $\mathrm{C}_{8} \mathrm{~S}_{5}$ dissociates at $\sim 525-625{ }^{\circ} \mathrm{C}$ at $7 \mathrm{MPa}$ and $\mathrm{CAS}_{2}$ then forms readily. In this temperature interval, a refractory might well suffer a loss of strength; the formation of $\mathrm{C}_{8} \mathrm{~S}_{5}$ appears to be undesirable. Its presence has not been observed in our work with other $\mathrm{CaO}-\mathrm{Al}_{2} \mathrm{O}_{3}-\mathrm{SiO}_{2}$ castables, even when quartz has been used as a source of silica. Its formation appears to be favored by the ready availability of all three components of $\mathrm{CAS}_{2}$.

7) It is difficult to estimate the effect of leaching by a gasification environment on the $\mathrm{CAS}_{2}$ and $\mathrm{A}_{3} \mathrm{~S}_{2}$ components of a CaO $-\mathrm{Al}_{2} \mathrm{O}_{3}-\mathrm{SiO}_{2}$ castable. However, available data suggest that refractories of this type are a desirable choice for the working face of a gasification reactor lining. As mentioned previously, bonding phase $\mathrm{CAS}_{2}$ develops rapidiy in the temperature interval $700-900{ }^{\circ} \mathrm{C}$ in the presence of steam. Free $\alpha-A$ reacts at $900-1000{ }^{\circ} \mathrm{C}$ to form $\mathrm{A}_{3} \mathrm{~S}_{2}$. Once formed, $\mathrm{CAS}_{2}$ persists when cooled from operating to ambient conditions of temperature and pressure.

Summary

The in situ $x$-ray studies have shown that, in the presence of steam and with changes in temperature, a high purity castable refractory is subjected to frequent changes in bonding phases and to intervals in which the main bonding phase is in a state of transition. These changes are undesirable and should be minimized by avoiding exposure of the refractories to steam below $750{ }^{\circ} \mathrm{C}$, or preferably $900{ }^{\circ} \mathrm{C}$. Reaction of the high purity refractory with steam containing alkalis and silica from impurities in the coal should be expected to occur at the working face with formation of various silicates. These may alter the course of hydration/dehydration reactions and the formation of bonding phases.

The $\mathrm{CaO}-\mathrm{Al}_{2} \mathrm{O}_{3}-\mathrm{SiO}_{2}$ refractory has been shown (Task 2) to increase markedly in flexural strength with exposure to either simulated or pilot plant gasification atmospheres. The increase in strength is attributed to the formation of $\mathrm{CAS}_{2}$ and $\mathrm{A}_{3} \mathrm{~S}_{2}$. Once formed, these compounds are not subject to hydration/dehydration and are stable in steam over a large temperature range. Leaching of silica and other components from this type of refractory has been observed, but may not pose a serious problem during the service life of the material. 

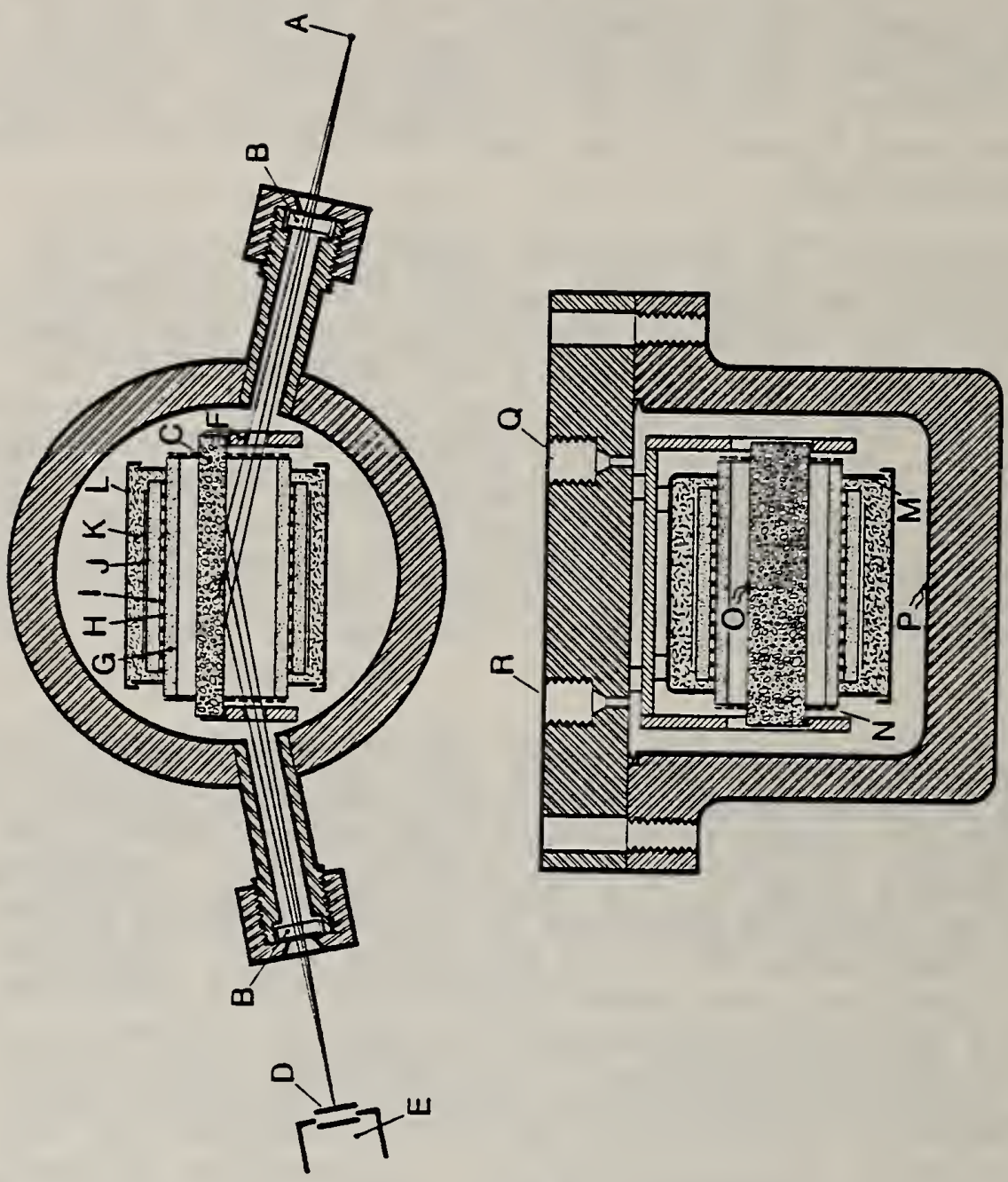

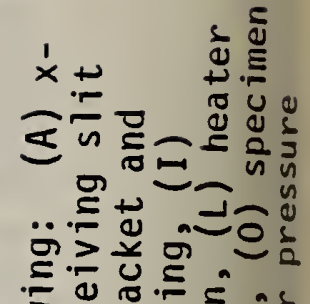
총 d 的 - כ㧒

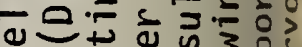
ज $E+\infty$ ข

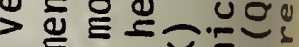
o

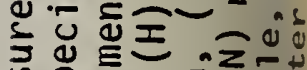
ต $2 . \cdots$ s

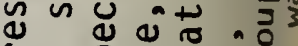

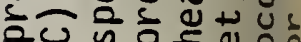
U 的皆它

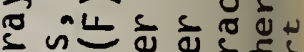

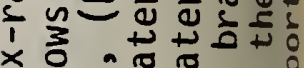

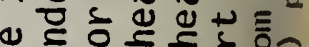

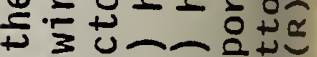

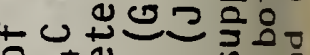
可告. n ㄷำ

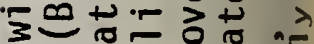

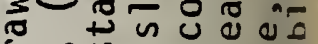

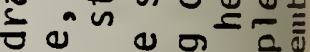
> U. 巳寸

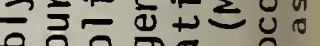
을 요요.

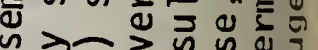

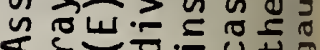

造 


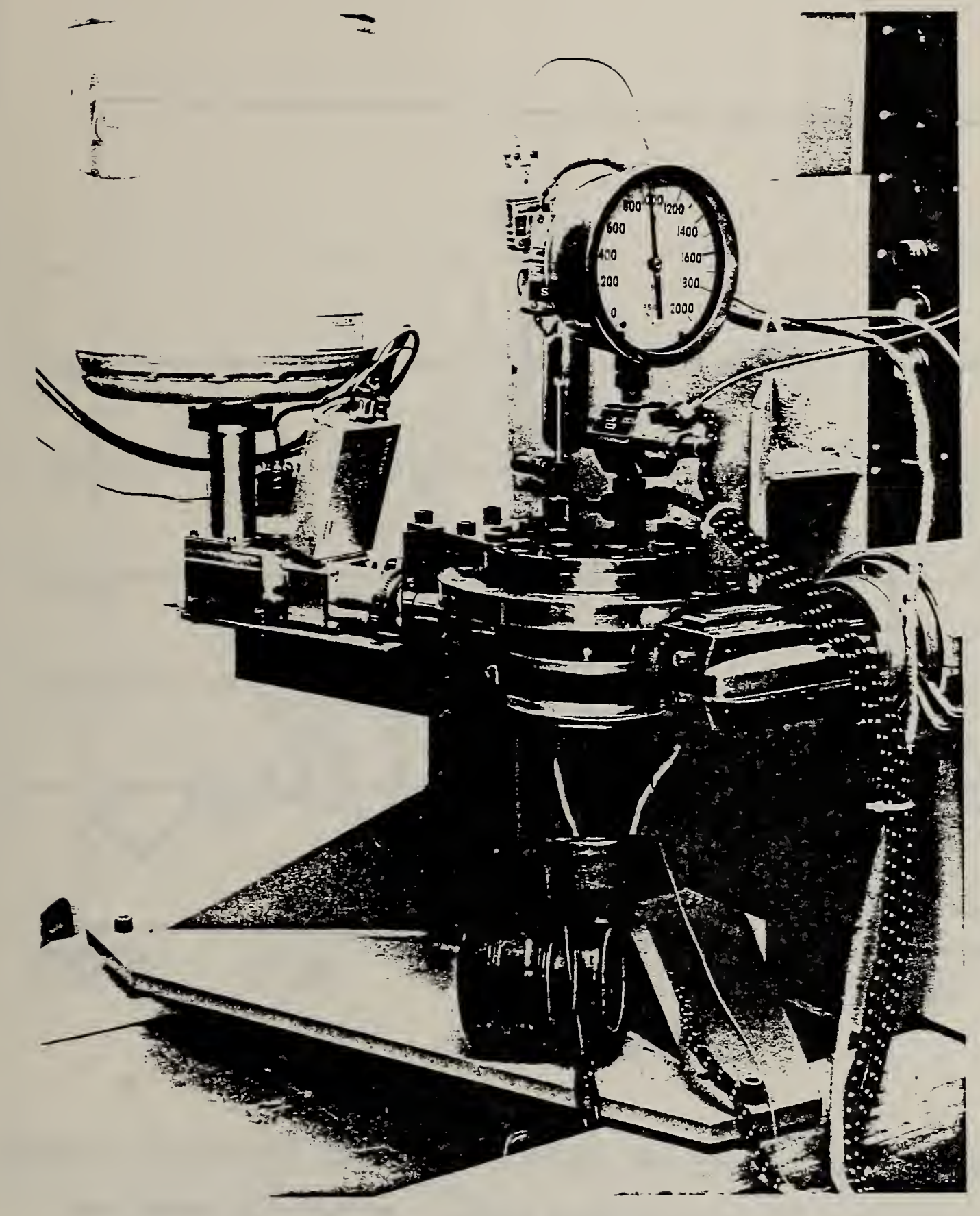

Figure 2. The pressure vessel and solid state detector mounted at the $x$-ray tube. 


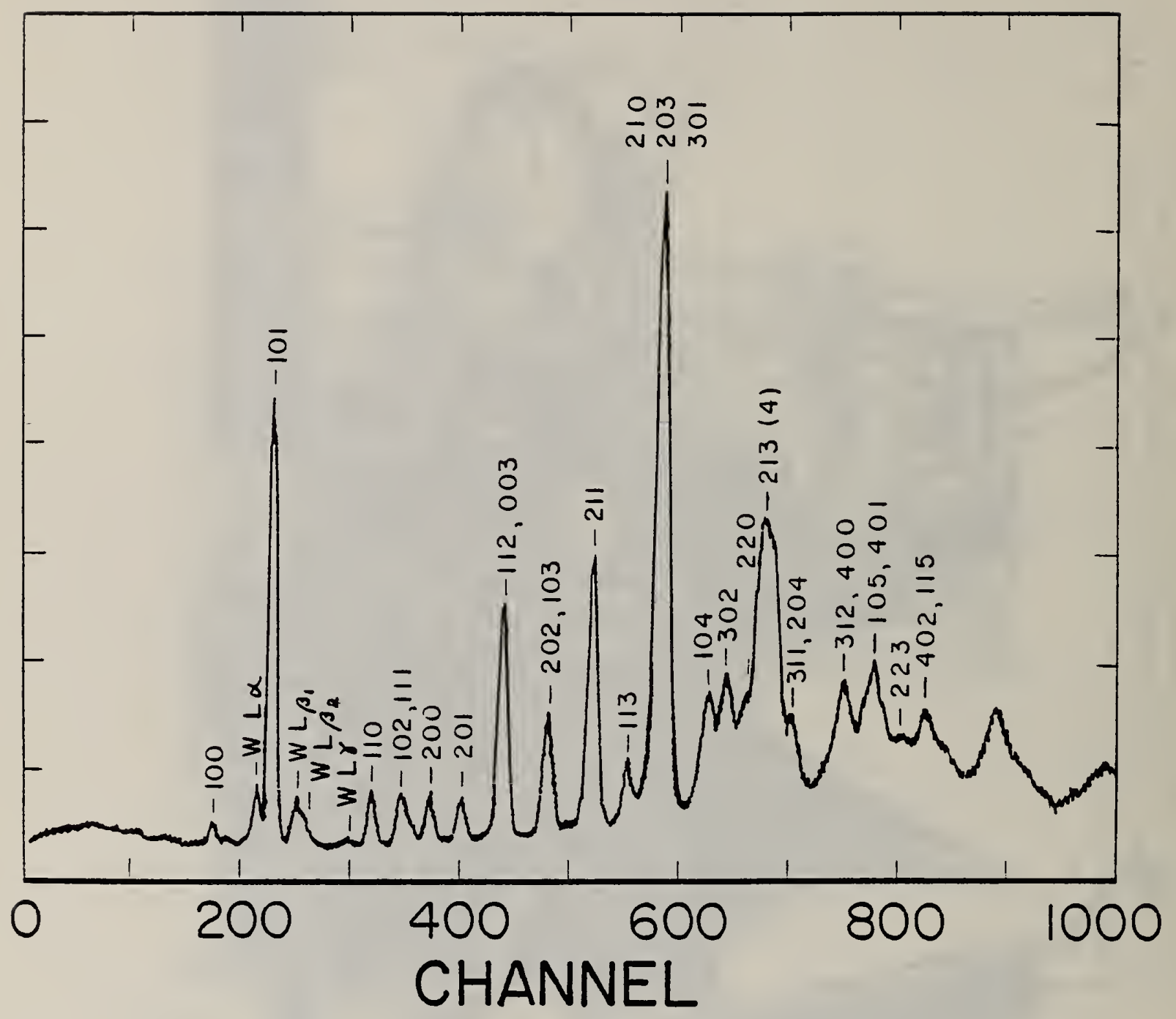

Figure 3. EDXD pattern of $\alpha$-quartz $\left(\mathrm{SiO}_{2}\right)$. Diffraction peaks are identified by their Miller indices. Four lines from the characteristic spectrum of the tungsten $x$-ray tube are al so identified ( $W L \alpha ; W L B_{1}, W L B_{2}$ and $W L Y$ ). 


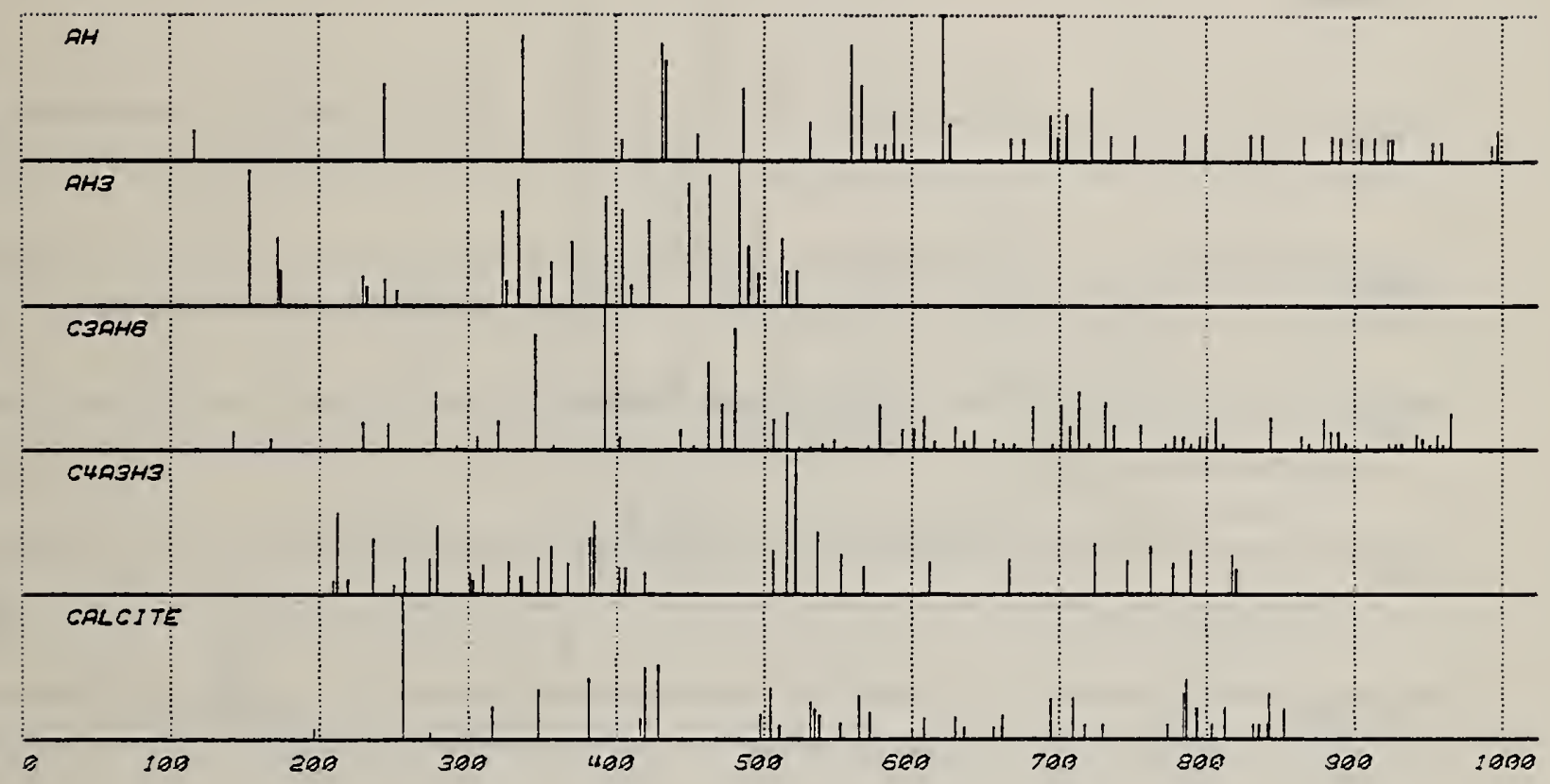

CHANNEL

Figure 4. Calculated EDXD patterns of $A H, A_{3}, C_{3} A H_{6}, C_{4} A_{3} H_{3}$, and $C \bar{C}$. 


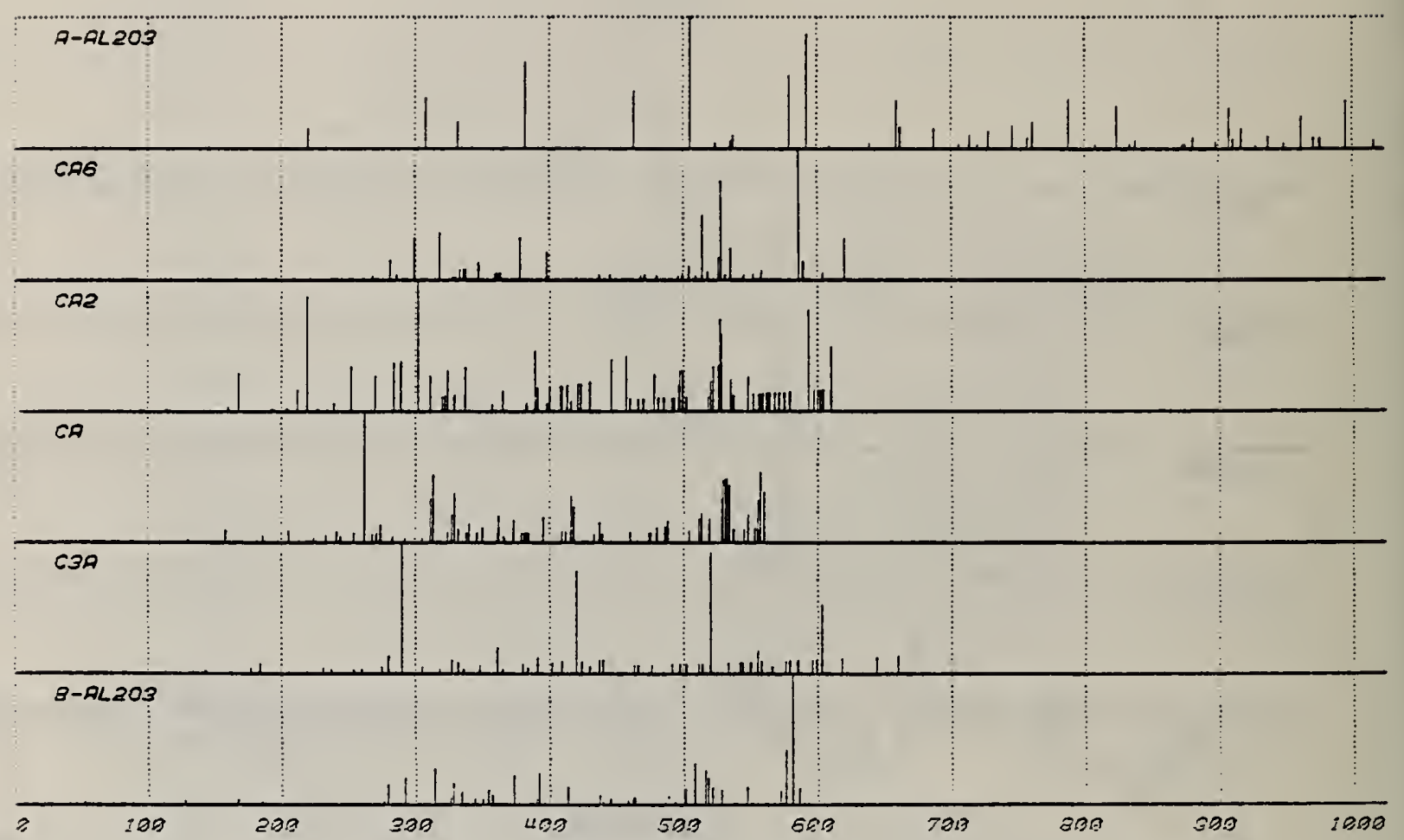

CHANNEL

Figure 5. Calculated EDXD patterns of $\alpha-A, C A_{5}, C A_{2}, C A, C_{3} A$, and $\beta-A$. 


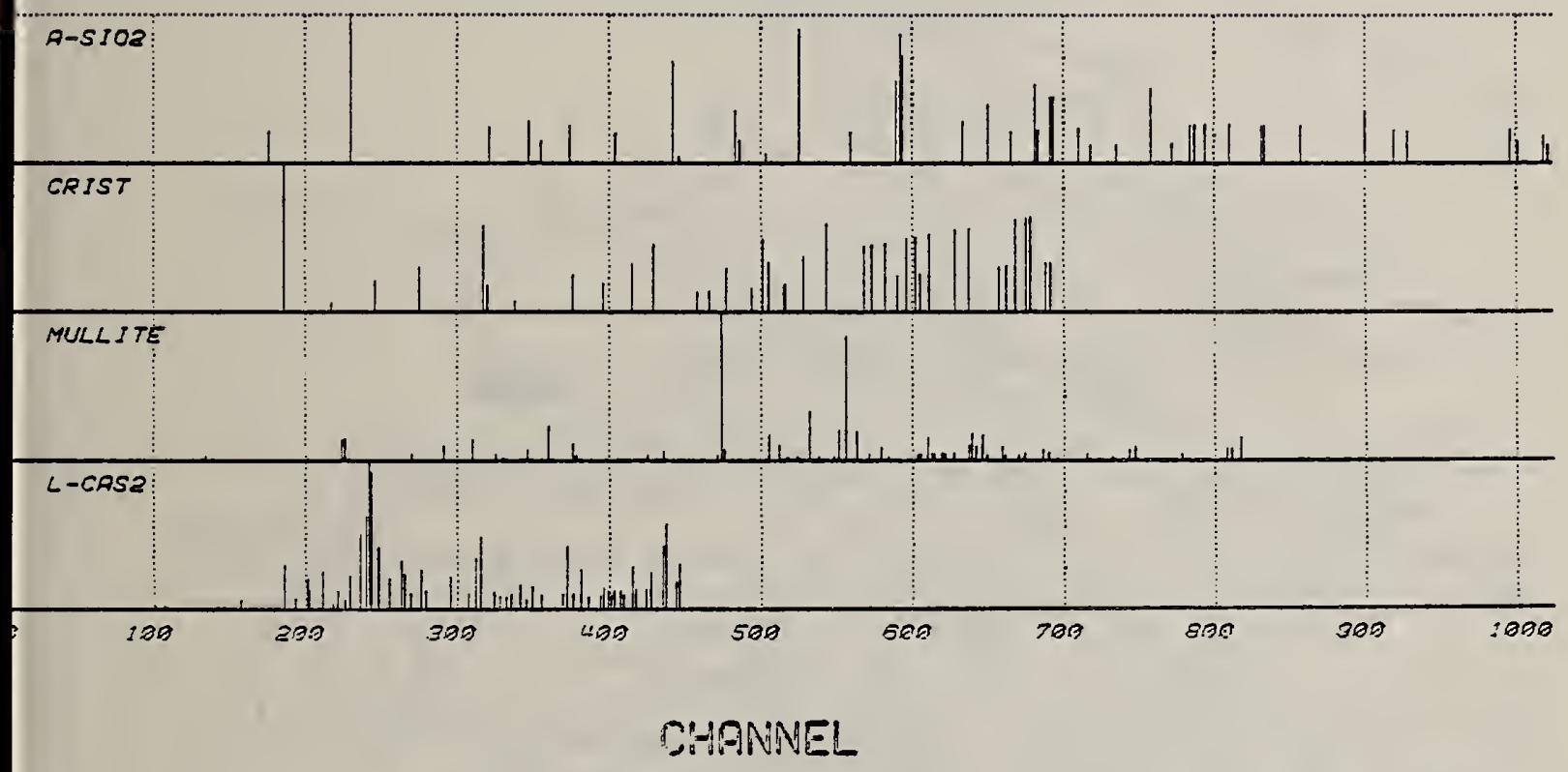

Figure 6. Calculated EDXD patterns of $\alpha-S_{q}$ (quartz), $S_{C}$ (cristobalite), $\mathrm{A}_{3} \mathrm{~S}_{2}$ (mul1ite), and low $\mathrm{CAS}_{2}$. 


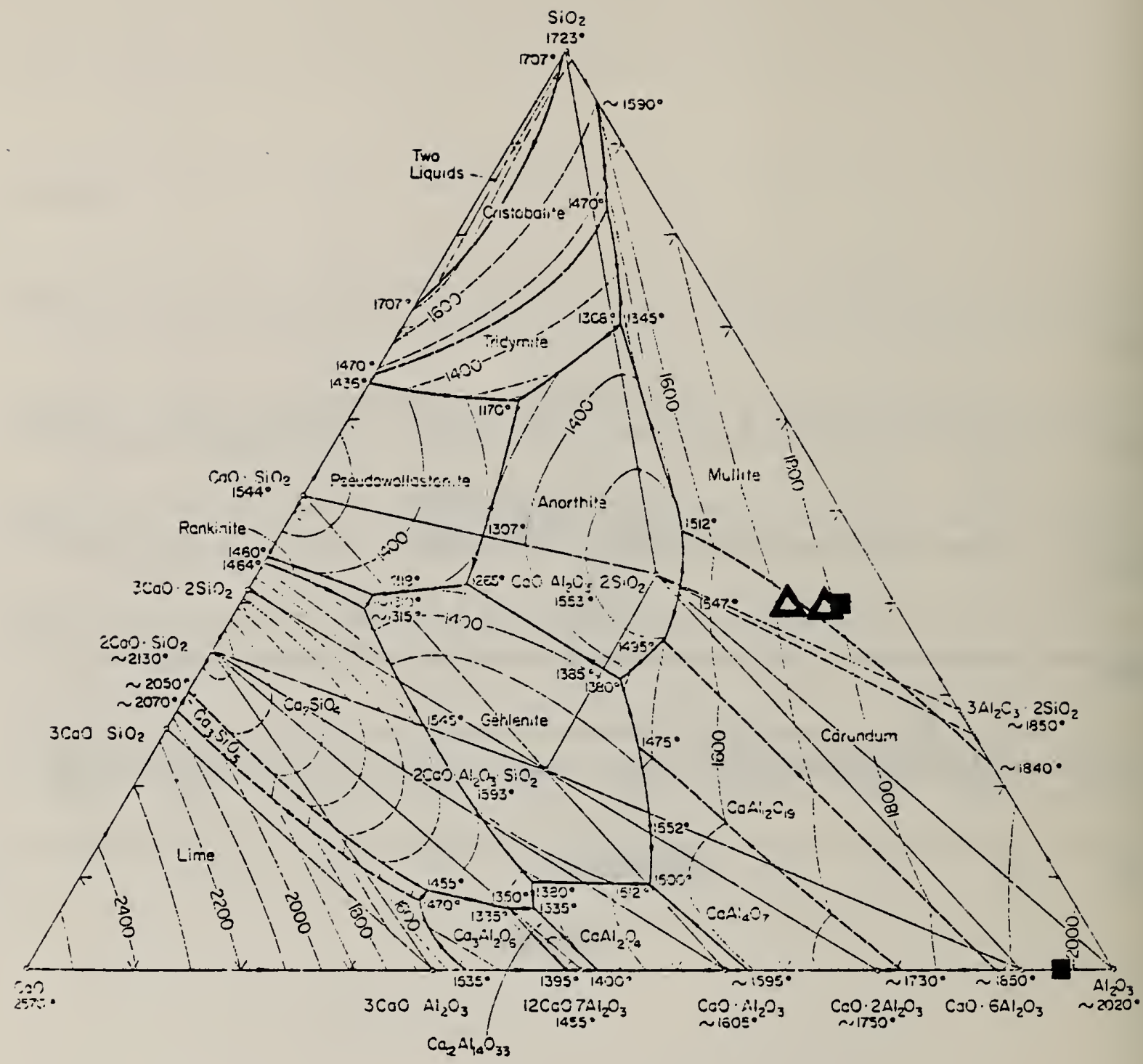

Figure 7. Phase diagram of the system $\mathrm{CaO}-\mathrm{Al}_{2} \mathrm{O}_{3}-\mathrm{SiO}_{2}$ showing the compositions of NBS castable refractories (solid squares). A-56 lies in the compatibilit) triangle $A_{3} S_{2}-C_{2} S_{2}-S$, while $A-94$ is on the join $\mathrm{CaO}-\mathrm{Al}_{2} \mathrm{O}_{3}$. The compositions of two commercial refractories used in the Conoco pilot plant are represented by open triangles. 


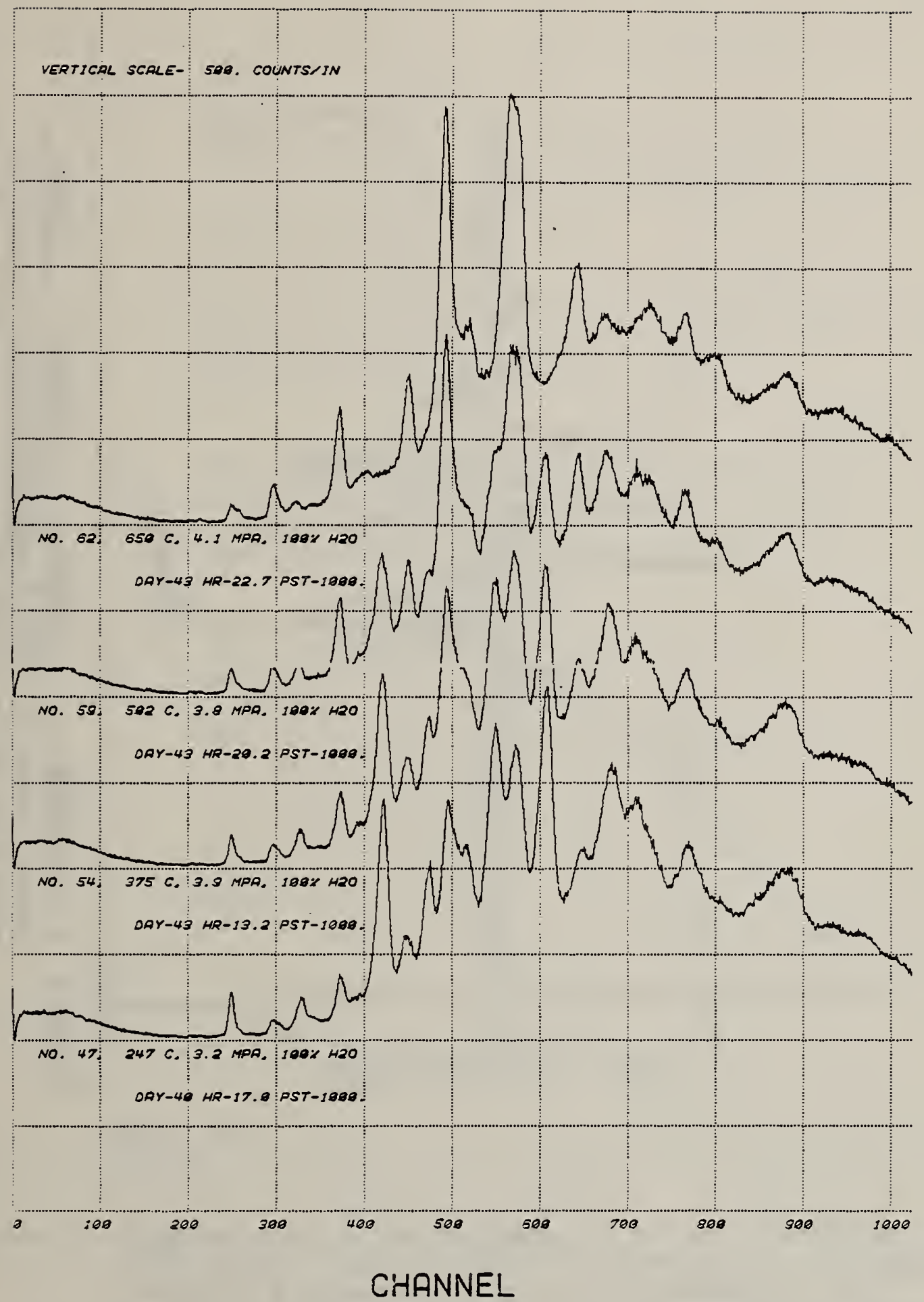

Figure 8. A series of four EDXD patterns showing the dissociation of $\mathrm{AH}$ (boehmite) and the formation of additional $\alpha-A$ in the range from $247^{\circ} \mathrm{C}$ and $3.2 \mathrm{MPa}$ to $650^{\circ} \mathrm{C}$ and $4.1 \mathrm{MPa}$. 


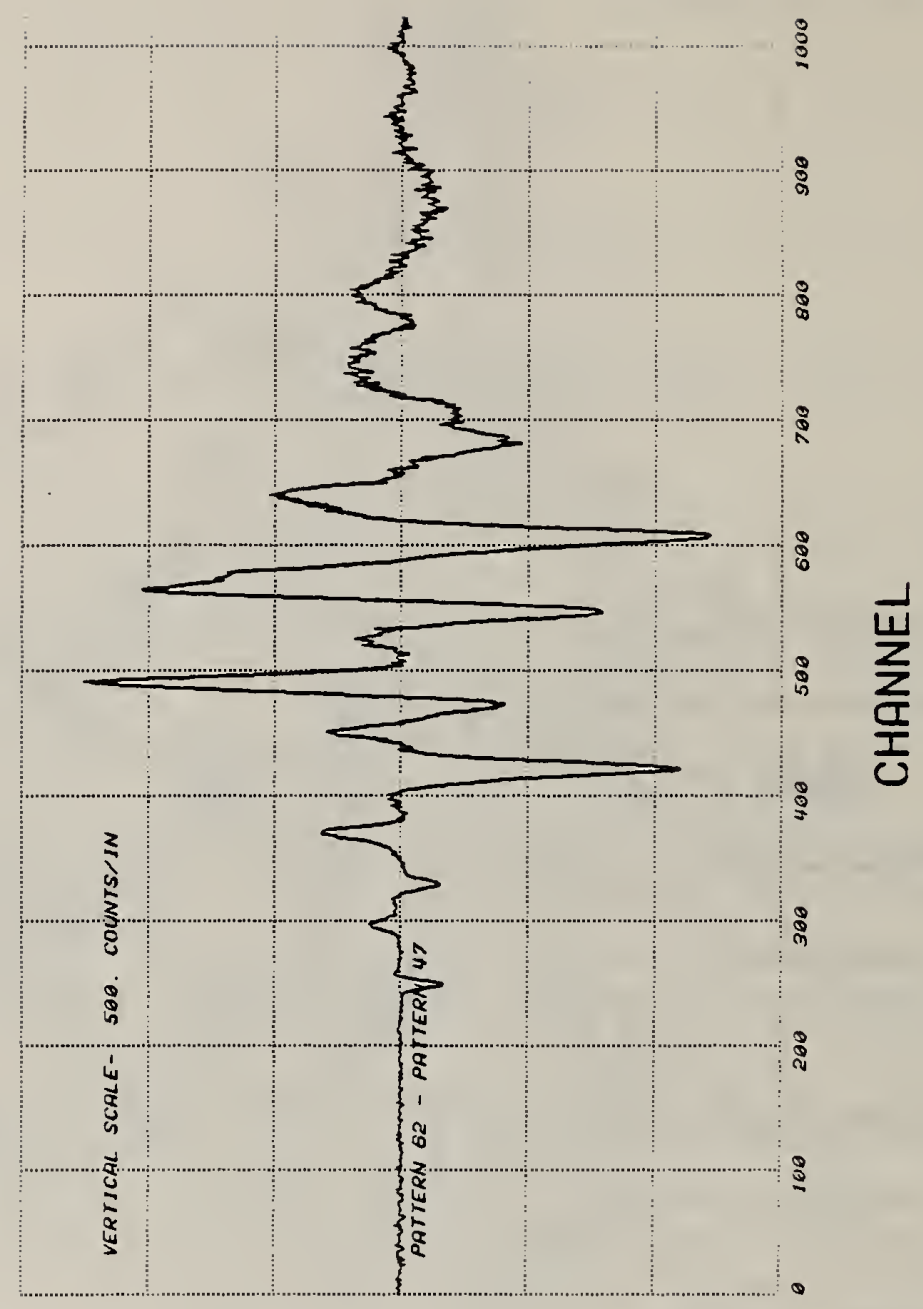

$\stackrel{2}{\frac{1}{2}}$

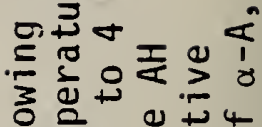
的的导志的 훵ㅇㅇㅇㅛ 于里政

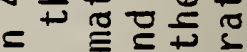
क्ष. 넝

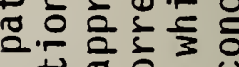
$1 \pm 00$

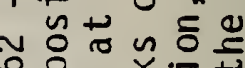
ช

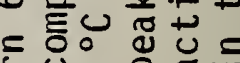
닝

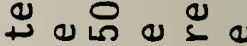

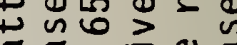
管

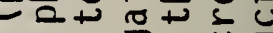

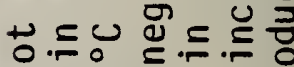
㩆导司 ญ 次

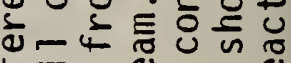

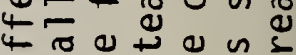
定的的

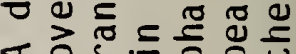
बं 


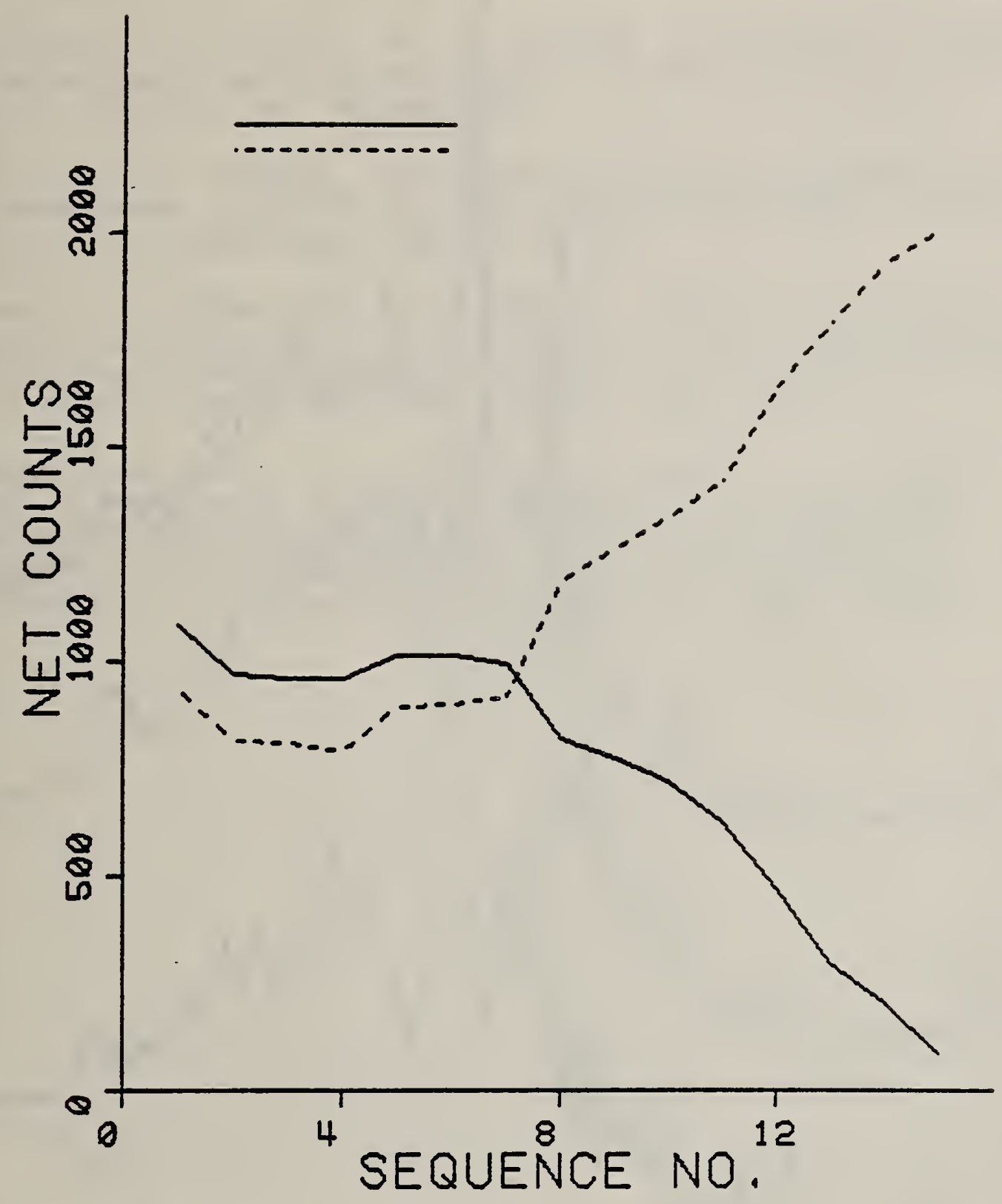

$A H \& A$

Figure 10. Computer plot of the intensity of the 251 reflection of $A H$ (solid line) and the 116 reflection of $\alpha-A$ (dashed line) for a sequence of fourteen experiments. The dehydration of $A H$ is evident in the temperature range from $375{ }^{\circ} \mathrm{C}$ to $650^{\circ} \mathrm{C}$ at a pressure of approximately $4 \mathrm{MPa}$. 


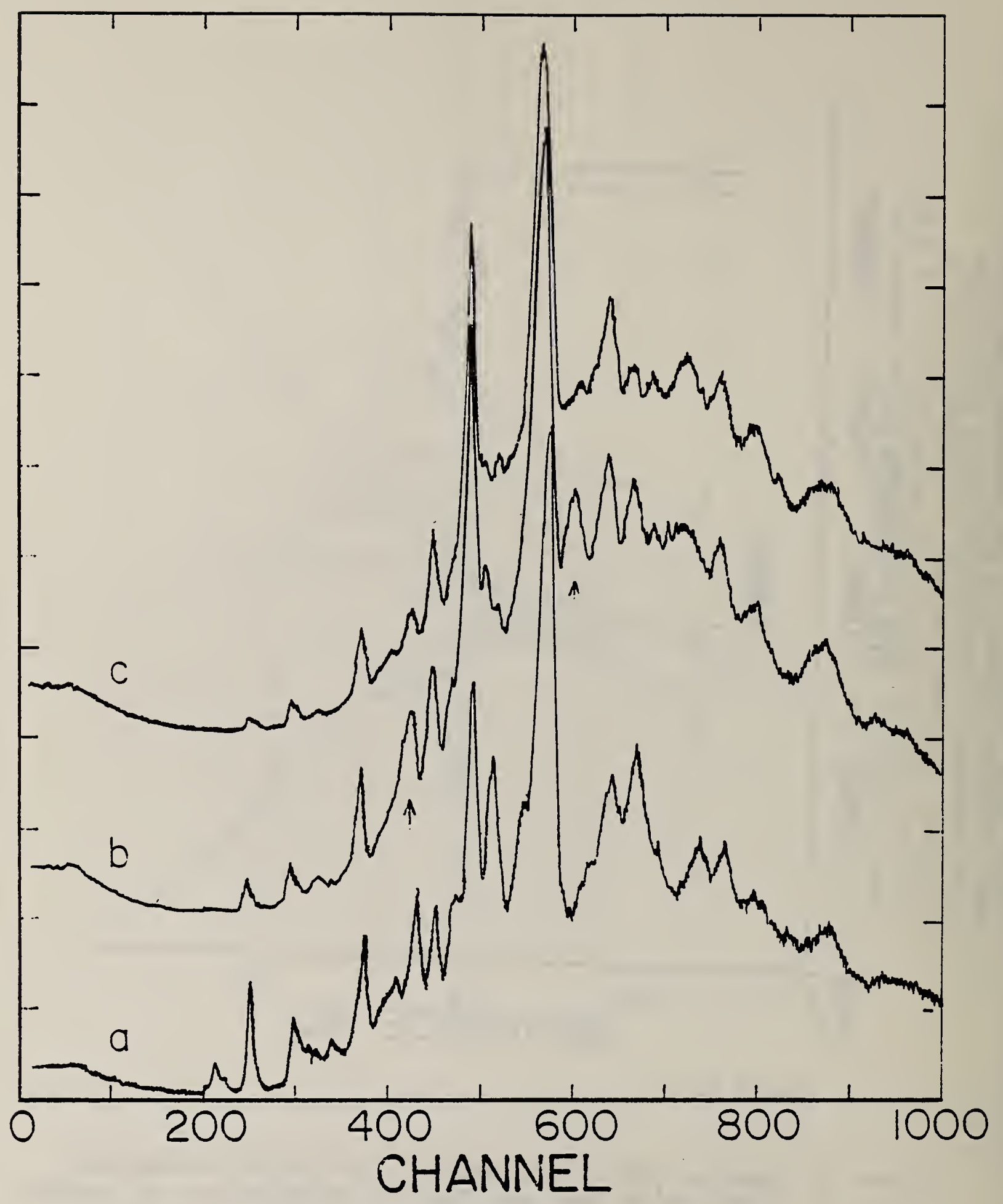

Figure 11. EDXD patterns of an unfired test bar of $\mathrm{CAS}_{2}$ (a) at $25{ }^{\circ} \mathrm{C}$, (b) at $520^{\circ} \mathrm{C}$ and $7 \mathrm{MPa}$ steam, and (c) at $625^{\circ} \mathrm{C}$ and $7 \mathrm{MPa}$ steam one hour later. Two lines of the $\mathrm{C}_{8} \mathrm{~S}_{5}$ phase are identified with arrows. 
F. A. Mauer and C. R. Robbins, "X-ray Powder Diffraction Measurements in Reactive Atmospheres at $1000^{\circ} \mathrm{C}$ and $7 \mathrm{MPa}$ ", Plenary Session, 27 th Annual Conference on Applications of X-ray Analysis, Denver, Colorado, August 2, 1978

S. M. Wiederhorn, E. R. Fuller, Jr., J. Bukowski, C. R. Robbins, "Effect of Hydrothermal Environments on the Erosion of Castable Refractories", J. Eng. Mater. Technol., 99, 143-146 (1977).

F. A. Mauer and C. R. Robbins, "X-ray Powder Diffraction Measurements in Reactive Atmospheres at $1000{ }^{\circ} \mathrm{C}$ and $7 \mathrm{MPa}$ (1000 psig) Advances in X-ray Analysis, Vol. 22, Plenum Press, New York (1979).

W. S. Brower, R. C. Dobbyn, and C. R. Robbins, "Laboratory Examination and Evaluation of the Gasifier Lining Used in the Conoco Lignite Gasification Pilot Plant", Materials and Components in Fossil Energy Applications, U. S. Department of Energy Publication, No. 24, June (1979).

R. C. Dobbyn, H. M. Ondik, W. A. Willard, W. S. Brower, I. J. Feinberg, T. A. Hahn, G. E. Hicho, M. E. Read, C. R. Robbins, J. H. Smith and S. M. Wiederhorn, "An Evaluation of the Performance of Materials and Components Used in the Conoco Lignite Gasification Pilot Plant $\mathrm{CO}_{2}$ Acceptor Process", U. S. Department of Energy Report (1979) In Press. 
VI. REFERENCES

1. "Materials Research for the Clean Utilization of Coal", Quarterly Progress Reports for the period September 1975 - September 1979, Center for Materials Science, National Bureau of Standards, Washington, D. C. 20234 (available from NTIS; report designation EA-6010; Dist. Category UC-90C).

2. S. M. Wiederhorn, E. R. Fuller, Jr., J. Bukowski, C. R. Robbins, "Effect of Hydrothermal Environments on the Erosion of Castable Refractories", J. Eng. Mater. Technol., 99, 143-146 (1977).

3. R. C. Dobbyn, H. M. Ondik, W. A. Willard, W. S. Brower, I. J. Feinberg, T. A. Hahn, G. E. Hicho, M. E. Read, C. R. Robbins, J. H. Smith, and S. M. Wiederhorn, "An Evaluation of the Performance of Materials and Components Used in the Conoco Lignite Gasification Pilot Plant $\mathrm{CO}_{2}$, Acceptor Process", U. S. Department of Energy Report (1979) In Press.

4. W. S. Brower, R. C. Dobbyn, and C. R. Robbins, "Laboratory Examination and Evaluation of the Gasifier Lining Used in the Conoco Lignite Gasification Pilot Plant", Materials and Components in Fossil Energy Applications, U. S. Department of Energy Publication, No. 24, June (1979).

5. B. C. Giessen and G. E. Gordon, "X-ray Diffraction: New High Speed Technique Based on X-ray Spectrography", Science 159, 973-975 (1968).

6. C. J. Sparks, Jr. and D. A. Gedcke, "Rapid Recording of Powder Diffraction Patterns with $S i(L i) X$-ray Energy Analysis System: W and Cu Targets and Error Analysis", Advances in X-ray Analysis, 15, 240-253 (1972).

7. Powder Diffraction File, JCPDS--International Centre for Diffraction Data, 1601 Park Lane, Swarthmore, PA 19081.

8. E. M. Levin, C. R. Robbins, and H. F. McMurdie, Phase Diagrams for Ceramists", Figure 630, The American Ceramic Society (1964).

9. E. M. Levin, C. R. Robbins, and H. F. McMurdie, Phase Diagrams for Ceramists - 1969 Supplement, Figure 4033, The American Ceramic Society (1969).

10. G. L. Davis, O. F. Tuttle, "Two New Crystalline Phases of the Anorthite Composition, $\mathrm{CaO} \cdot \mathrm{Al}_{2} \mathrm{O}_{3} \cdot 2 \mathrm{SiO}_{2}$ ", Am. J. Sci., Bowen Vol., $107-114(1952)$.

11. K. Speakman, H. F. W. Taylor, and (in part) J. M. Bennett and J. A. Gard, "Hydrothermal Reactions of $\gamma$-Dicalcium Silicate", J. Chem. Soc. (A), 1052-1060 (1967). 


\section{U.S. DEPT. OF COMM. \\ BIBLIOGRAPHIC DATA SHEET}

1. PUBLICATION OR REPORT NO.

NBSIR $80-2064$

4. TITLE AND SUBTITLE

CHEMICAL DEGRADATION OF CASTABLE REFRACTORIES IN COAL GASIFICATION PROCESS ENVIRONMENTS

5. Publication Date

May 1980

5. Performing Organization Code

8. Performing Organ. Report No.

7. AUTHOR(S)

C. R. Robbins and F. A. Mauer

9. PERFORMING ORGANIZATION NAME AND ADDRESS

18. Project/Task/Nork Unit No.

NATIONAL BUREAU OF STANDARDS

DEPARTMENT OF COMMERCE

WASHINGTON, DC 20234

12. SPONSORING ORGANIZATION NAME AND COMPLETE ADDRESS (Streot, City, State, zIP)

13. Type of Report \& Period Covered

14. Sponsoring Agency Code

15. SUPPLEMENTARY NOTES

E Document describes a computer program; SF-185, FIPS Software Summary, is attached.

16. ABSTRACT (A 200-word or loas factual summary of most signiticant information. If documont includes a significant bibliography of literature survay, montion it hare.)

Reactions and transiormations that result in chemical decradation of castable refractories used as liners for coal gasification rezctcrs have been studied. In addition to phase analysis of laboratory and pilot plant specimens by conventional x-ray powder diffraction, a na's test method was dayeloped that permits changes in the phase composition to be observed without removing the specimen from the test atmosphere. Two cancidate castahle refractories were included in the sudy, a high purity $\mathrm{CaO}-\mathrm{Al}_{2} \mathrm{O}_{3}$ composition with tabular aiumina aggregate ( 33.7 wit: $\mathrm{Al}_{2} \mathrm{C}_{3}, 5.6 \mathrm{wt}: \mathrm{C2O}$ ) and a. $\mathrm{CaO}-\mathrm{Al}_{2} \mathrm{C}_{3}-\mathrm{SiO}_{2}$ composition with calcined kaolinite aggregate $\left(55\right.$ wt: $\mathrm{Al}_{2} \mathrm{O}_{3}, 36$ wt \% $\mathrm{SiO}_{2}, 5$ wt \% CaO). Specimens mere exposed to steam, steam/CO , and a simulated coal gasification atmosphere at a pressure of $7 \mathrm{MP}$ (1000 psig) and temperatures up to $1000^{\circ} \mathrm{C}$. Frequent changes in the bonding phases, and intervals in which a bording phase was in transition were observed in the case of the high purity castable reiractory. The silica-containing reiraztory, on the other hand, formed bonding ohases which were stable in staam over a large range of temperatures and pressures.

17. KEY WORDS (six to walve entrieo; alphabetical order; capitalize only the first letter of the tirst kay word unlesd a proper name separated by semicolons)

Coal; degradation; durabiitity; environment testing; gasification; refractories;

18. AVAILABILITY Unlimited

For Official Distribution. Do Plot Release to NTIS

Order From Suo. of Doc., U.S. Government Printing Office, Nashington, DC 20402, SD Stock No. SNÖ03-003-

X Order From National Technical Information Service (NTIS), Springiield, vA. 22161

\begin{tabular}{|c|c|}
\hline $\begin{array}{l}\text { 19. SECURITY CLASS } \\
\text { (THIS REPORT) } \\
\text { UNCLASSIFIED }\end{array}$ & $\begin{array}{l}\text { 21. NO. OF } \\
\text { PRINTED PAGES } \\
30\end{array}$ \\
\hline $\begin{array}{l}\text { 20. SECURITY CLASS } \\
\text { (THIS PAGE) } \\
\text { UNCASSIFIED }\end{array}$ & $\begin{array}{l}\text { 22. Price } \\
\$ 6.00\end{array}$ \\
\hline
\end{tabular}


